\title{
DETECTION OF MIXED MICROBIAL BIOFILMS ON CENTRAL VENOUS CATHETERS REMOVED FROM INTENSIVE CARE UNIT PATIENTS
}

\author{
Anisio Storti; Antonio Carlos Pizzolitto; Elisabeth Loshchagin Pizzolitto* \\ Faculdade de Ciências Farmacêuticas, Universidade Estadual Paulista, Araraquara, SP, Brasil \\ Submitted: December 12, 2003; Returned to authors for corrections: September 09, 2004; Approved: September 20, 2005
}

\begin{abstract}
Central venous catheters from intensive care unit patients were subjected to microbiological methods (semiquantitative culture) and scanning electron microscopy in order to assess microbial attachment and correlate it with blood cultures. During the period of the survey, 59 patients with inserted central venous catheters were studied. The type of catheter used was nontunneled, noncuffed, single lumen, made of polyurethane. Blood samples for cultures were collected at the moment of catheter removal. Data on the patient's age, gender, catheter insertion site, and duration of catheterization were also obtained. From 63 catheters tips analysed, $30(47.6 \%)$ showed microbial colonization. Infection proved to be more prevalent in $26(41.3 \%)$ patients with catheters inserted via subclavia vein than in $2(3.2 \%)$ inserted via the jugular vein. Infection was observed more frequently in catheters which were kept in place more than seven days. $A$. baumannii, Citrobacter freundii, E. aerogenes, P. aeruginosa and S. saprohyticus were isolated as causal agents of catheter-related bloodstream infections. The antimicrobial agent with greater in vitro activity against Gram-negative bacteria was imipenen and against Gram-positive were vancomycin, cefepime, penicillin, rifampin and tetracycline. The SEM analyses revealed biofilms on surfaces of all the catheters examined.
\end{abstract}

Key words: biofilm, bacteremia-catheter, central venous catheter, microorganisms attachment

\section{INTRODUCTION}

Central venous catheters are widely used in critically ill patients in intensive care units. However their use is often complicated by catheter-related bloodstream infections $(9,25)$. Independent of the source of microorganisms colonizing intravascular catheters, some of them have the capability of causing catheter-related bloodstream infections (20), which derive from a complex interaction between microorganism, biomaterial and host, that determines the development of infection (20). The pathogenesis of catheter-related bloodstream infections has been associated to sessile multicellular communities of microorganisms with individual bacteria cells embedded in an extra-cellular polysaccharide matrix known as biofilms, which development involves initial attachment of the microorganism to a surface, the formation of microcolonies, and, finally, differentiation of microcolonies into exopolysaccharideencased mature biofilms $(4-9,11,14)$.

Examination of a contaminated central venous catheter by scanning electron microscopy (SEM) showed the surface covered with a biofilms, composed of host proteins and microcolonies of the infecting organism encased in a thick matrix of glycocaliyx (slime) (15). Both microbial (slime) and host (fibrin and fibronectin) factors contribute to the formation of the biofilm, which is essencial for the adherence and maintenance of the colonization (22).

These infections can only be treated by removal of the catheter, thus increasing the cost of treatment. It has been estimated that biofilms are associated with $65 \%$ of nosocomial infections (12). These findings have been considered the pathogenetic basis for recommending the semiquantitative culture technique as a usefull method of diagnosing catheter-

*Corresponding Author. Mailing address: Faculdade de Ciências Farmacêuticas, Campus de Araraquara, CRD-NAC-setor de Microbiologia Clínica. Rua Expedicionários do Brasil, 1621. CEP: 14801-360. E-mail: pizzolel@fcfar.unesp.br 
related infections, since this technique cultures the external surface of catheters $(11,13,23)$, in which the growth of at least 15 colony forming units (CFU) has been considered evidence of catheter infection and increase a risk of bacteremia (13). The aim of this study was to detect, by the roll-plate method and scanning electron microscopy (SEM), microbial biofilms on central venous polyurethane catheters surfaces used in an intensive care unit, to characterize the microorganisms associated to these, and relate these findings to the risk of bloodstream infection.

\section{MATERIALS AND METHODS}

\section{Patients and catheter evaluation assays}

The present study was carried out on adult patients of both sexes, between the ages of 20 to 88 years ( 63.2 years average), hospitalized in an intensive care unit (ICU) at the northeast region of the State of São Paulo. Patients were accepted into the study after careful analysis, and inclusion was approved by the local Ethics Committee of the hospital.

This study included all patients which were catheterized in the ICU. Exclusion criteria were patients transferred to other units of the hospital or who had the catheters removed accidentally.

Over a seven months period, 59 out of 105 patients from the ICU receiving single lumen polyurethane central venous catheters (20cm length, Becton, Dickinson Indústrias Cirúrgicas, Juiz de Fora, MG, Brasil), were selected for the study. Depending on the clinical diagnosis, catheterization was prescribed and performed by the doctor on duty in the ICU, in accordance with the standard techniques, either through the subclavian or jugular vein. The catheters were removed and $10 \mathrm{~mL}$ of blood taken from peripheral veins, by standard venipuncture, were cultured using Oxoid Signal BC100 System (Hampshire, England), and catheter tips were sent for culture using Maki semiquantitative techniques (13).

The distal tips of the catheters $(4$ to $5 \mathrm{~cm}$ ) were processed and the inoculated agar plates were incubated at $37^{\circ} \mathrm{C}$ for $72 \mathrm{~h}$ and colonies enumerated. After semiquantitative culture, the catheters tips were immersed in sterile Mueller Hinton broth and incubated at $37^{\circ} \mathrm{C}$ overnight under orbital shaking (100rpmMarconi-Piracicaba, São Paulo, Brazil) (21). The objective was to increase the grow of microorganisms attached to the catheter and facilitate SEM visualization of the biofilm. In vitro studies have shown that bacteria in a liquid medium multiply on the surfaces of catheters, and various amounts of glycocalyx are evident $(14,15)$.

Catheter-tip infection has been defined as microbial growth of $\geq 15$ cfu per semiquantitative agar plate (13) and catheterrelated bacteremia was considered to be present if the same organism (species and antibiogram) was isolated from the catheter-tip and blood cultures (22-25).

\section{Identification of Microorganisms}

Identification were determined by using standard microbiological procedures $(4,16)$.

\section{Antimicrobial Susceptibility Testing}

This assay was carried out according to NCCLS methodology (19). The antimicrobial agents were all obtained from Cecon-São Paulo-Brasil and include cephalosporins (cephalothin, cefazolin, cefuroxime, cefoxitin, cefotaxime, ceftazidime and cefepime), penicillins (ampicillin, penicillin, amoxicillin, and oxacillin), betalactamase inhibitor combinations (amoxicillin-clavulanate and ticarcillin-clavulanate), carbapenems (imipenem), a monobactam (aztreonam), fluoroquinolones (ciprofloxacin and levofloxacin), aminoglycosides (amikacin, kanamycin, gentamicin, and tobramycin), macrolides (azithromycin), glycopeptides (vancomycin), and other drugs, such as clindamycin, chloramphenicol, tetracycline, rifampin, and sulfamethoxazole.

\section{Scanning electron microscopy}

After overnight incubation all catheters tips were removed from the tubes and kept for $15 \mathrm{~min}$ at room temperature in 2.5\% glutaraldehyde in $0.1 \mathrm{M}$ phosphate buffer (pH7.1), dehydrated using an ethanol series $(15 \%, 30 \%, 50 \%, 70 \%, 95 \%$ and $100 \%)$ for $15 \mathrm{~min}$ each, dried in a vacuum centrifuge and sputter-coated with gold. The inner and outer surfaces of the catheters tips were examined by SEM (JEOL-JSM T330A- Japan) at 20kV and photographed (21).

\section{RESULTS AND DISCUSSION}

The 59 patients from ICU studied had been hospitalized from one to fifthy-two days (13.7 day average). The pathologies included: brain vascular accident 14 (23.7\%), chronic kidney insufficient $5(8.5 \%)$, chronic pulmonary obstruction 11 (8.7\%), mellitus diabetes $5(8.5 \%)$, traumatized $3(5.1 \%)$, digestive hemorrhage $2(3.4 \%)$, anaphylactic shock $1(1.7 \%)$ and others pathologies $13(22.0 \%)$. Central venous catheters were inserted either into the right subclavian vein $51(86.4 \%)$, left subclavian vein $4(6.8 \%)$ or jugular vein $4(6.8 \%)$. The patients were catheterized for periods from 1-30 days (9.1 day average) and catheters were removed for the following reasons: death 38 (64.4\%), inflammation at the point of insertion $13(22.0 \%)$, release from hospital $3(5.1 \%)$, pain $1(1.7 \%)$, wrong position of catheter $1(1.7 \%)$, suspension of intravenous therapy $1(1.7 \%)$, leucocytosis $1(1.7 \%)$ and at the criterion of the doctor $1(1.7 \%)$. From the 59 patients participating in the study, 63 catheters were removed and analysed.

The results of semiquantitative cultures taken from the catheter tips, showed that $30(47.6 \%)$ had microorganisms growth with $\geq 15$ colony forming units, 11 (17.5\%) growth of microorganism with $\leq 15$ colony forming units and in 22 (34.9\%) no microbial growth was observed. 
From the cultures that showed growth, 180 strains were isolated and $48(44.5 \%)$ were classified as Gram-positive. Among these, 32 were coagulase-negative Staphylococcus (29.6\%), including Staphylococcus cohnii 1 (0.9\%), Staphylococcus epidermidis 1 (0.9\%), Staphylococcus haemolyticus 14 (13.0\%); Staphylococcus lugdunensis 2 (1.9\%), Staphylococcus saprophyticus 2 (1.9\%), Staphylococcus xylosus 1 (0.9\%), and Staphylococcus warneri 11 (10.2\%); 9 were coagulase-positive Staphylococcus (8.3\%) including Staphylococcus intermedius $8(7.4 \%)$ and Staphylococcus hyicus $1(0.9 \%)$; 5 were diphteroid rods (4.6\%), and 2 Streptococcus of viridans group (1.8\%). From the 57 Gram-negative bacteria $(52.7 \%)$ isolated, 9 were Acinetobacter baumannii (8.3\%); 1 Acinetobacter lwoffi (0.9\%), 2 Burkholderia cepacea (1.9\%), 1 Citrobacter freundii (0.9\%), 5 Enterobacter aerogenes (4.6\%); 4 Enterobacter cloacae (3.7\%), 1 Flavobacterium meningosepticum (0.9\%), 1 Klebsiella ozaenae (0.9\%), 18 Pseudomonas aeruginosa (16.7\%); 1 Pseudomonas putida (0.9\%), 1 Roseomonas spp (0.9\%) and 2 Stenotrophomonas maltophilia (1.9\%). Fungi, were also isolated, including 1 Candida albicans $(0.9 \%), 1$ Candida parapsilosis (0.9\%) and 1 Candida lusitaniae (0.9\%).

Findings of coagulase-negative Staphylococcus, Pseudomonas aeruginosa and Candida albicans isolated from catheter tips corresponds with data from other autors (8). Studies have shown that $C$. albicans is the most commonly isolated yeast, and other species are found with increasing frequency, including C. parapsilosis, as notified by Safdar et al. (27), and C. lusitaniae, observed Yoon et al. (28). Our data shows nonalbicans species isolation from catheter tip, such as $C$. parapsilosis and C. lusitaniae. According to, Raad and Bodey (23), infections due to Candida parapsilosis could be related to catheter use. Yoon et al. (28) isolated C. lusitaniae from a catheter tip suggesting it as the source of candidemia, and revealed an increase in the incidence of serious infections caused by this fungus, due to its sporadic resistance to amphotericin B.

In relation to the frequency of isolation of coagulasenegative Staphylococcus, it was observed with less frequency than that seen by Moro et al. (18). The presence of nonfermentative Gram-negative Pseudomonas aeruginosa and Acinetobacter baumanii were noted with more frequency, in agreement with the data reported by Morayta-Ramirez et al. (17) and Karlowsky et al. (10). The presence of Flavobacterium meningosepticum was noticed not only in our research, but in the study of Murray et al. (16). These rods were found in hospital environments, specially the intensive care units, and were also named as Chryseobacterium meningosepticum, which are the species most often associated with significant disease in humans.

Our data showed that the bacteria isolated from catheter tips involved bacterial species which are commensals with the human body, or are common in the environments. Costerton et al. $(4,6)$ noted that the skin bacterium Staphylococcus epidermidis and the aquatic bacterium Pseudomonas aeruginosa can cause chronic infections in compromised hosts.

In $14(66.7 \%)$ blood cultures, 5 (23.8\%) proved positive for bacterial growth and $9(42.9 \%)$ were shown to be negative. Table 1 lists the microorganisms responsible for contaminated catheters, and cases with concomitant bacteremia.

Our findings suggest that $23.8 \%$ catheters were related to bloodstream infections, a percentage much higher than that reported by Maki (14), who noted that central venous catheters pose a greater risk of device-related infection than does any other indwelling medical device, with infections rates of 3 to 5\%. Our data showed that $A$. baumannii was responsible for $18.2 \%$ of ICU-acquired bloodstream infections, after $E$. aerogenes $(36.4 \%)$ and P. aeruginosa (27.3\%). Bullard and Dunn (3) observed that Gram-negative bacteria was accounted for approximately $30 \%$ of all episodes of bacteremia at most institutions, and Enterobacter aerogenes, Enterobacter cloacae, Escherichia coli, Klebsiella pneumoniae, and Pseudomonas aeruginosa were isolated. As recorded by Karlowsky et al. (10), Pseudomonas aeruginosa and Acinetobacter baumannii are the most prevalent nonfermentative bacterial species isolated from clinical specimens of hospitalized patients. Studies from Blot et al. (2), evaluating the clinical impact of nosocomial Enterobacter bacteremia in critically ill patients, indicated that these bacteria are increasingly emerging nosocomial pathogens because antibiotic-resistant susceptibility patterns easily developed in these pathogens.

In respect to the detection of biofilm on central venous catheter surfaces, our data showed that microorganisms attached on catheter surfaces formed microcolonies, produced extracellular polymeric substances and encased the cells, which was in good agreement with Costerton et al. (6) and Donlan (7). The extracellular biofilm matrix visualized by scanning electron

Table 1. Microorganisms isolated from blood culture and catheter tips.

\begin{tabular}{lcccc}
\hline \multirow{2}{*}{ Microorganisms } & \multicolumn{2}{c}{$\begin{array}{c}\text { Catheter } \\
\text { tips }\end{array}$} & \multicolumn{2}{c}{$\begin{array}{l}\text { Blood } \\
\text { cultures }\end{array}$} \\
\hline & $\mathrm{n}^{\mathrm{o}}$ & $\%$ & $\mathrm{n}^{\circ}$ & $\%$ \\
\cline { 2 - 5 } Acinetobacter baumannii & 2 & 14.3 & 2 & 18.2 \\
Candida lusitaniae & 1 & 7.1 & 0 & 0 \\
Citrobacter freundii & 1 & 7.1 & 1 & 9.1 \\
Enterobacter aerogenes & 4 & 28.6 & 4 & 36.4 \\
Pseudomonas aeruginosa & 3 & 21.4 & 3 & 27.3 \\
Staphylococcus intermedius & 2 & 14.3 & 0 & 0 \\
Staphylococcus saprophyticus & 1 & 7.1 & 1 & 9.1 \\
\hline Total & 14 & 100 & 11 & 100 \\
\hline
\end{tabular}


microscopy (Fig. 1) appear as amorphous material on a surface, in agreement with Donlan (7).

All the contaminated catheters and bloodstream infections showed agreement between the organisms isolated from the blood and that detected on the catheter surface after SEM. This agreement was based on morphology. By the criteria previously defined, cocci and rods forms were visualized on both surfaces of the central venous catheters (Fig. 1), from all five patients with bacteremia (Table 2).

Also, based on SEM observation, our results indicated a universal colonization of the organisms on indwelling central venous catheters by rods and cocci embbeded in the biofilm (Fig. 1). The cocci, rods and yeast morphologies seen by the SEM, and the detection of Staphylococcus intermedius, Staphylococcus saprophyticus, Acinetobacter baumanii,

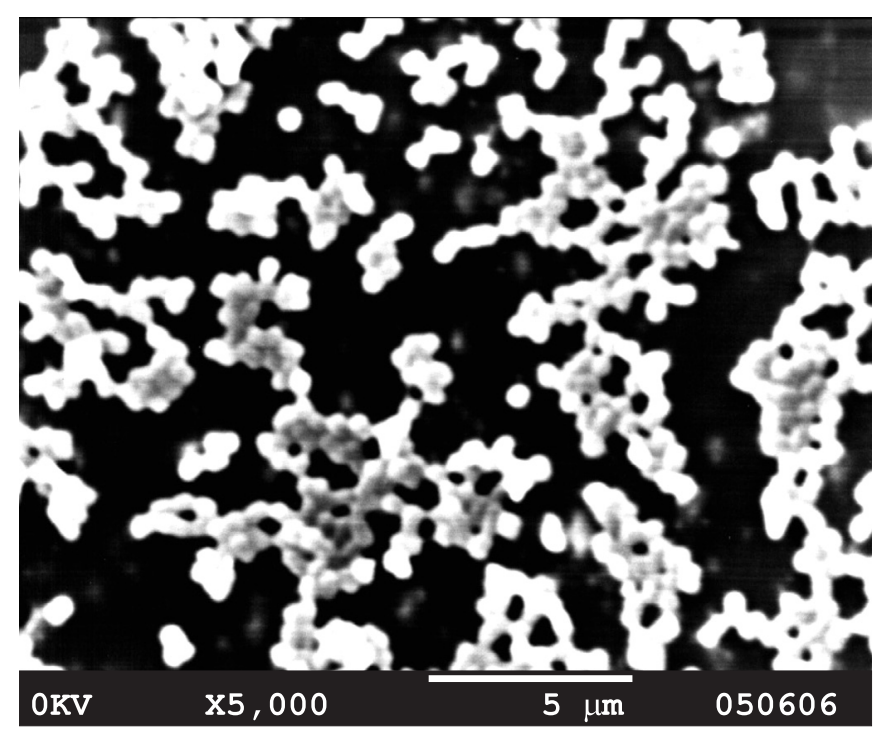

Figure 1. SEM image of the internal surface of a central venous polyurethane catheter tip, from a patient with catheter-related bacteremia, after cultivation in Mueller Hinton broth.

Table 2. Morphological aspects of microorganisms on catheter tip surfaces from patients with bacteremia.

\begin{tabular}{clll}
\hline Patients & \multicolumn{1}{c}{ Catheter tips } & Blood culture & SEM analysis \\
\hline 1 & $\begin{array}{l}\text { Gram-negative rods } \\
\text { Gram-negative rods } \\
\text { and Gram-positive cocci }\end{array}$ & $\begin{array}{l}\text { Gram-negative rods } \\
\text { Gram-negative rods }\end{array}$ & $\begin{array}{l}\text { rods } \\
\text { rods and cocci }\end{array}$ \\
9 & $\begin{array}{l}\text { Gram-negative rods } \\
\text { and Gram-positive cocci } \\
\text { Gram-negative rods }\end{array}$ & Gram-negative rods & rods and cocci \\
37 & $\begin{array}{l}\text { Gram-positive cocci } \\
\text { and yeasts }\end{array}$ & Gram-positive cocci & $\begin{array}{l}\text { rods } \\
\text { rods, cocci } \\
\text { and yeasts }\end{array}$ \\
\hline
\end{tabular}

Enterobacter aerogenes and Pseudomonas aeruginosa indicated that autochthonous skin organisms, as well as intestinal microbiota or microorganisms common in the environment, may play an important role in catheter colonization, as suggested by Goldmann and Pier (9). In study, by definition, infections caused by these microorganisms have one thing in common: the presence of a plastic intravenous catheter.

The microbe-catheter interaction involves a series of interrelated steps, including adherence, colonization and dissemination (4-8). Other investigators using SEM, such as Raad et al. (24), noted that biofilms were commonly present on central venous catheters and were associated with either outer or inner catheter surfaces. Donlan (7) showed that virtually all indwelling central venous catheters were colonized by microorganisms embedded in a biofilm matrix, and Costerton $e t$ al. (6) reported that the bacteria in many device-related infections grow in matrix-enclosed biofilms that cannot be penetrated by antibodies or by phagocytes. Moreover, the sessile cells in these biofilms adopt a radically different phenotype from floating (planktonic) cells of the same species, and are much less susceptible to antibiotics.

Our results of susceptibility tests for A. baumanni, E. aerogenes and $P$. aeruginosa cultured from blood are shown in Table 3. Our findings showed that only carbapenems had activity against the A. baumanni isolates evaluated. Tetracycline, tobramycin and sufamethoxazole inhibited in vitro $50 \%$ of the isolates. Others antimicrobials were not active against this organism. Karlowsky et al. (10) demonstrated that $96.6 \%$ of $A$. baumannii isolated from ICU patients were susceptible to imipenem, fewer isolates were susceptible to amikacin and ticarcillin-clavulanate (80\%); and $<60 \%$ of isolates were susceptible to ceftazidime, ciprofloxacin, gentamicin or levofloxacin.

In relation to susceptibility testing it was noted that all $E$. aerogenes strains were susceptible to imipenem and resistant to third generation cephalosporins and beta-lactamase inhibitor combinations. Our data are consistent with previous studies of Sader et al. (26).

Our results showed that all $P$. aeruginosa strains cultured from blood were susceptible to carbapenems. However, ceftazidime did not have activity against these strains. Our findings are consistent with Sader et al. (26), who noted that carbapenem (imipenem) is the third most active compound against this pathogen in Brazil, after meropenem and piperacillin/tazobactam. Also, these authors observed that $P$. aeruginosa isolated from ICU had a tendency to express higher resistance rates. Karlowsky et al. (10) found $>90 \%$ of isolates of $P$. aeruginosa from hospitalized patients to be susceptible to amikacin; 80 to $90 \%$ of isolates to be susceptible to cefepime, ceftazidime and imipenem; and 70 to $80 \%$ of isolates to be susceptible to ciprofloxacin, 
Table 3. Antibiotic susceptibility patterns of bacteria cultured from blood samples

\begin{tabular}{lcccccc}
\hline & \multicolumn{5}{c}{$\begin{array}{c}\text { Bacteria isolated from blood } \\
\text { cultures (number tested) }\end{array}$} \\
\cline { 2 - 7 } \multicolumn{1}{c}{ Antibiotics } & $\begin{array}{c}\text { A. baumannii } \\
\text { (2) }\end{array}$ & $\begin{array}{c}\text { E. aerogenes } \\
\text { (4) }\end{array}$ & $\begin{array}{c}\text { P. aeruginosa } \\
\text { (3) }\end{array}$ \\
\cline { 2 - 7 } & $\mathrm{S}$ & $\mathrm{R}$ & $\mathrm{S}$ & $\mathrm{R}$ & $\mathrm{S}$ & $\mathrm{R}$ \\
\hline Amikacin $(30 \mu \mathrm{g})$ & 0 & 2 & 1 & 3 & 1 & 2 \\
Amoxicillin- & & & & & & \\
Clavulanate $(30 \mu \mathrm{g})$ & - & - & 0 & 4 & - & - \\
Ampicillin $(10 \mu \mathrm{g})$ & - & - & 0 & 4 & - & - \\
Aztreonam $(30 \mu \mathrm{g})$ & 0 & 2 & 0 & 4 & 1 & 2 \\
Kanamycin $(30 \mu \mathrm{g})$ & - & - & 1 & 3 & - & - \\
Cephalothin $(30 \mu \mathrm{g})$ & - & - & 0 & 4 & - & - \\
Cefazolin $(30 \mu \mathrm{g})$ & - & - & 0 & 4 & - & - \\
Ceftazidima $(30 \mu \mathrm{g})$ & 0 & 2 & - & - & 0 & 3 \\
Cefepime $(30 \mu \mathrm{g})$ & 0 & 2 & 1 & 3 & 2 & 1 \\
Cefotaxime $(30 \mu \mathrm{g})$ & 0 & 2 & 0 & 4 & 0 & 3 \\
Cefoxitin $(30 \mu \mathrm{g})$ & - & - & 0 & 4 & - & - \\
Cefuroxime $(30 \mu \mathrm{g})$ & - & - & 0 & 4 & - & - \\
Ciprofloxacin $(5 \mu \mathrm{g})$ & 0 & 2 & 1 & 3 & 1 & 2 \\
Chloranphenicol $(30 \mu \mathrm{g})$ & 0 & 2 & 1 & 3 & 0 & 3 \\
Gentamicin $(10 \mu \mathrm{g})$ & 0 & 2 & 1 & 3 & 1 & 2 \\
Imipenem $(10 \mu \mathrm{g})$ & 2 & 0 & 4 & 0 & 3 & 0 \\
Levofloxacin $(5 \mu \mathrm{g})$ & 0 & 2 & - & - & 3 & 0 \\
Netilmicin $(30 \mu \mathrm{g})$ & 0 & 2 & 1 & 3 & 1 & 2 \\
Sulfamethoxazole $(25 \mu \mathrm{g})$ & 1 & 1 & 1 & 3 & 0 & 3 \\
Tetracycline $(30 \mu \mathrm{g})$ & 1 & 1 & 1 & 3 & 0 & 3 \\
Tobramycin $(10 \mu \mathrm{g})$ & 1 & 1 & 1 & 3 & 1 & 2 \\
Ticarcillin- & & & & & \\
calvulanate $(10 \mu \mathrm{g})$ & 0 & 2 & - & - & 0 & 3 \\
\hline
\end{tabular}

\section{ACKNOWLEDGMENTS}

The authors wish to thank Doris E. Barnes for English revision and the Centro de Referência Diagnóstica do Núcleo de Atendimento à Comunidade da Faculdade de Ciências Farmacêuticas, UNESP Araraquara (SP, Brasil), for financial support.

\section{RESUMO}

\section{Detecção de biofilmes microbianos mistos em cateters venosos de pacientes de Unidades de Terapia Intensiva}

Cateteres venosos centrais inseridos em pacientes internados em unidade de terapia intensiva foram avaliados por métodos microbiológicos (cultura semi-quantitativa) e microscopia eletrônica de varredura a fim de detectar adesão microbiana e correlacionar com a cultura de sangue. Durante o período de estudo, foram avaliados 59 pacientes com cateter venoso central. A idade dos pacientes, sexo, sítio de inserção e tempo de permanência do cateter foram anotados. $\mathrm{O}$ cateter era de poliuretano não tunelizado e de único lúmen. O sangue para cultura foi coletado no momento da remoção do cateter. De 63 pontas de cateteres, $30(47,6 \%)$ foram colonizadas e a infecção encontrada em $5(23,8 \%)$ cateteres. A infecção foi mais prevalente em 26 pacientes $(41,3 \%)$ com cateteres inseridos em veia subclávia do que $\operatorname{nos} 3(3,2 \%)$ inseridos em veia jugular. A infecção foi observada com mais frequiência em cateteres com tempo de permanência maior do que sete dias. Os microrganismos isolados incluíram 32 estafilococos coagulase-negativa $(29,7 \%), 61$ bactérias Gramnegativas $(52,9 \%), 9$ estafilcocos coagulase-positiva

gentamicin, levofloxacin, ticarcillin-clavulanate, and decreases in antimicrobial susceptibility (percents) in ICU patients was observed for ciprofloxacin, levofloxacin, and ceftazidime.

In the current study the susceptibility testing for Gramnegative microorganisms isolated from catheter tips and blood cultures showed that they were resistant to aminoglicosides, aminopenicilins, third generation cephalosporins and quinolones.

\section{CONCLUSION}

Our study suggests that the presence of biofilm on the catheter surface can become a nidus of bloodstream infection in patients. Future studies increasing knowledge of biofilm formation on plastic surfaces and host interactions could prevent and decrease this type of infection.
$(8,3 \%)$ e 3 leveduras $(2,7 \%)$. Como agentes causais de infecções em unidade de terapia intensiva foram isolados $E$. aerogenes, $P$. aeruginosa, A. baumannii. Os antimicrobianos com maior atividade in vitro contra as bactérias Gram-negativas foram o imipenem e contra as Gram-positivas vancomicina, cefepime, penicilina, rifampicina e tetraciclina. As análises por microscopia eletrônica de varredura revelaram biofilmes sobre a superfície de todos os cateteres examinados.

Palavras-chave: biofilme, cateter-bacteriemia, cateter venoso central, aderência de microrganismos

\section{REFERENCES}

1. Bernardi, A.C.A.; Pizzolitto, E.L.; Pizzolitto, A.C. Identificação de cocos aeróbios Gram-positivos, catalase positiva com implicação em processos infecciosos. Rev. Cienc. Farm., 22, 223-238, 2001. 
2. Blot, S.I.; Koenraad, M.A.; Vandewoude, H.; Colardyn, F.A. Evaluation of outcome in critically ill patients with nosocomial Enterobacter bacteremia. CHEST, 123, 1208-1213, 2003.

3. Bullard, K.M.; Dunn, D.L. Diagnosis and treatment of bacteremia and intravascular catheter infections. Am. J. Surg., 172, 13-19, 1996.

4. Costerton, J.W.; Cheng, K.J.; Geesey, G.G.; Ladd, T.I.; Nickel, J.C.; Dasgupta, M.; Marrie, T.J. Bacterial biofilms in nature and disease. Annu. Rev. Microbiol., 41, 435-464, 1987.

5. Costerton, J.W.; Lewandowski, Z.; Caldwell, E.D.; Korber, D.R., Lappin-Scott, H.M. Microbial biofilms. Annu. Rev. Microbiol., 49, 711-145, 1995.

6. Costerton, J.W.; Stewart, P.S.; Greenberg, E.P. Bacterial biofilms: a common cause of persistent infections. Science, 284, 1318-1322, 1999.

7. Donlan, R.M. Biofilms and device-associated infections. Emerg. Infect. Dis., 7, 277-281, 2001.

8. Donlan, R.M.; Costerton, J.W. Biofilms: Survival mechanisms of clinically relevant microorganisms. Clin. Microbiol. Rev., 15, 167193, 2002.

9. Goldman, D.A.; Pier, G.B. Pathogenesis of infections related to intravascular catheterization. Clin. Microbiol. Rev., 6, 176-192, 1993

10. Karlowsky, J.A.; Jones, M.E.; Draghi, D.C.; Thornsberry, C.; Sahm, D.F.; Volturo, G.A. Prevalence and antimicrobial susceptibilities of bacteria isolated from blood cultures of hospitalized patients in the United States in 2002. Ann. Clin. Microbiol. Antimicrob., 3, 1-8, 2004.

11. Liñares, J.A.; Sitges-Serra, A.; Garau, J.; Pérez, J.L.; Martin, R. Pathogenesis of catheter sespis: a prospective study with quantitative and semiquantitative cultures of catheter hub and segments. J. Clin. Microbiol., 21, 357-360, 1985.

12. Mah, T.F.C.; Toole, G.A.O. Mechanisms of biofilm resistance to antimicrobial agents. Trends Microbiol., 9, 34-39, 2001.

13. Maki, D.G.; Weise, C.E.; Sarafin, H.W. A semiquantitative culture method for identifying intravenous-catheter-related infection. $N$. Engl. J. Med., 296, 1305-1309, 1977.

14. Maki, D. G. Pathogenesis, prevention, and management of infections due to intravascular devices used for infusion therapy. p.155-212. In: Bisno, A.L.; Waldvogel, F.A. (ed.) Infections associated with indwelling medical devices. 2nd ed. ASM, Washington, 1994.

15. Marrie, T.J.; Costerton, J.W. Scanning and Transmission electron microscopy of in situ bacterial colonization of intravenous and intraarterial catheters. J. Clin. Microbiol., 19, 687-693, 1984.
16. Murray, P.R.; Baron, E.J.; Pfaller, M.A.; Tenover, F.C.; Yolken, R.H. Manual of Clinical Microbiology, 8ed., ASM, Washington, 2003.

17. Morayta-Ramirez, A; Rodrigues-Melo, F.I.; Gómez-Altamiro, C.M.; Ayala-Franco, J.R.; Gonzáles-Arenas, E. Agentes etiológicos causantes de infecciones nosocomiales relacionadas com cateteres intravasculares. Bol. Med. Hosp. Infant. Mex., 56, 648-653, 1999.

18. Moro, M.L., Viganó, E.F.; Lepri, A.C. Risk factors for central venous catheter-related infections in surgical and intensive care units. Infect. Control. Hosp. Epidemiol., 15, 253-264, 1994.

19. National Committee for Clinical Laboratory Standards. Performance Standards for Antimicrobial Disk Susceptibility Tests: ApprovedSeventh Edition, M2-A7. NCCLS, Wayne, PA, USA, 2000.

20. Pascual, A. Patogenesis of catheter-related infections: lessons for new designs. Clin. Microbiol. Infect., 8, 256-264, 2002.

21. Pizzolitto, E.L.; Ito, I.Y.; Guastaldi, A.C. Corrosion Induced by Streptococcus mutans (in vitro) Observed on Restorative Dental Materials. In: INTERNATIONAL EFC WORKSHOP, 4th, 1999, Portugal. Microbial Corrosion: proceedings. Grã-Bretanha: The European Federation of corrosion/IOM Communications, 2000. p.179-181. (European Federation of Corrosion Publ., n. 29).

22. Raad, I.I. The patogenesis and prevention of central venous cateterrelated infections. Middle East J. Anesthesiol., 12, 381-403, 1994.

23. Raad, I.I.; Bodey, G.P. Infectious complications of indwelling vascular catheters. Clinic. Infect. Dis., 15, 197-210, 1992.

24. Raad, I.I.; Costerton, W.; Sabharwal, U.; Sacilowski, M.; Anaissie, E.; Bodey, G.P. Ultrastructural analysis of indwelling vascular catheters: a quantitative relationship between luminal colonization and duration of placement. J. Infect. Dis., 168, 400-407, 1993.

25. Raad, I.I.; Hanna, H.A. Intravascular catheter-related infections. Arch. Intern. Med., 162, 871-878, 2002.

26. Sader, H.S.; Gales, A.C.; Pfaller, M.A.; Mendes, R.F.; Zoccoli, C.; Barth, A.; Jones, R.N. Pathogen frequency and resistance patterns in Brazilian hospitals: summary of results from three years of the SENTRY antimicrobial surveillance program. Braz. J. Infect. Dis., 5, 200-214, 2001.

27. Safdar, A.; Perlin, D.S.; Armstrong, D. Hematogenous infections due to Candida parapsilosis: changing trends in fungemic patients at a comprehensive cancer center during the last four decades. Diagn. Microbiol. Infect. Dis., 44, 11-16, 2002.

28. Yoo, S.A.; Vazquez, J.A.; Steffan, P.E.; Sobel, J.D.; Akins, R.A. Highfrequency, in vitro reversible switching of Candida lusitaniae clinical isolates from amphotericin B susceptibility to resistance. Antimicrob. Agents Chemoter., 43, 836-845, 1999. 